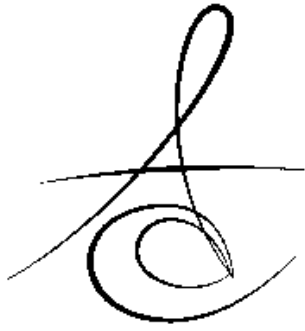

Makale Kodu/Article code: 2028

Makale Gönderilme tarihi: 17.12.2014

Kabul Tarihi: 15.04.2015

\section{OZON TEDAVİSİ VE Dİş HEKİMLİĞİNDEKİ KULLANIM ALANLARI}

\section{OZONE TREATMENT AND ITS USAGE IN DENTISTRY}

Arş. Gör. Dt. Hümeyra YAZAR*

Arş. Gör. Dt. Elif PEKER*

\author{
Prof. Dr. İnci Rana KARACA*
}

\section{ÖZET}

Ozon terapisi uzun yıllardır tıpta çeşitli hastalıkların tedavisinde başarı ile uygulanmaktadır. Non-invaziv uygulama seçenekleri ve düşük maliyete sahip olması sebebiyle diş hekimliğinde de kullanıma girmiştir. Doğada; ultraviole ışık sayesinde oksijen moleküllerinin fotolizi sonucu oluşmaktadır. Ozon terapisinin temel etki mekanizması, hücre düzeyinde kronik oksidatif stresi arttırmaktır. Buna ek olarak ozon; antimikrobiyal, bağışıklık sistemini düzenleyici, metabolizma hızını ve biyosentezi arttırıcı etkilere sahiptir. Yapılan çalışmalarda elde edilen sonuç; diş hekimliğinde ozon terapisinin diğer tedavilere yardımcı bir uygulama olarak kabul edilmesi gerektiğidir. Bu derlemenin amacl; ozonun terapötik etkisi ve klinikte kullanım alanlarına yönelik fikir vermektir.

Anahtar kelimeler: Ozon, Diş hekimliği

\section{ABSTRACT}

Ozone therapy has successfully being used in the treatment of various diseases in medicine over the years. Ozone is used in dentistry because of noninvasive implementation options and having low-cost. Ozone is produced naturally by photo dissociation of molecular oxygen. Ozone treatment's main effect is to increase chronic oxidative stress in cells. In additional that, it has antimicrobial, immunoregulatory, enhancing biosynthesisand metabolic rate properties. Study results show that ozone should be accepted as an adjuvant therapy to main treatments in dentistry. The aim of this review is to give an opinion about therapeutic effect of ozone and its usage in clinical practice.

Key words: Ozone, Dentistry

\section{OZON TEDAVİsi VE DİŞ HEKİMLİĞİNDEKí KULLANIM ALANLARI \\ Ozonun Tanımı}

Triatomik bir molekül olan ozon, 3 oksijen atomunun bir araya gelmesiyle oluşmakta ve ortamda gaz halinde bulunmaktadır. Ortam koşullarına bağı olarak ISI ve basınç değişimleriile yarılanma ömrü değişebilen ozon gazı stabil olmaması sebebiyle depo edilememektedir. Doğada; oksijen molekülünün fotolizi sonucu meydana gelen aktive oksijen atomları daha fazla oksijen molekülüyle tepkimeye girerek ozonu oluşturmaktadır. ${ }^{1-4}$

1840 ' da ilk defa Shonbein bu gaz için "ozon" adını kullanmıştır. Ozonun klinik uygulamalarının araştırılması uzun zamandır yapılmaktadır. 1880' de Amerika ' da ozon terapisi tıpta alternatif bir yöntem olarak kabul edilmiştir ve 130 yıldan daha uzun süredir tüm dünyada kullanılmaktadır. Ozon gazı 1. Dünya Savaşı́nda Alman askerlerdeki post-travmatik kazeöz gangrenler, enfekte yaralar, hardal gazı yanıkları ve fistüllerin tedavisinde kullanılmıştır. Fish, 1930' larda ozonu diş hekimliği pratiğinde kullanan ilk kişi olmuştur. Fish; ozonlanmış suyu cerrahide dezenfeksiyon ve yara iyileşmesi için kullanmıştır. 3,5

Günümüzde ozon terapisi Avrupa' da diş hekimliği ve tıpta yaygın olarak kullanılmaktadır. Ozon tedavisi; gaz şeklinde veya su ya da yağ içinde çözünmüş olarak terapötik yarar sağlamak amacıyla uygulanan çok yönlü biyo-oksidatif bir uygulamadır. ${ }^{3}$

\section{Etki mekanizması}

Ozonun diş hekimliği ve tıpta potansiyel uygulama alanları vardır. Bilinen bazı etkileri; antimikrobiyal, bağışıklık sistemini düzenleyici, antiinflamatuar, biyosentezi arttırıcı, enerji metabolizmasını hızlandırıcı,

* Gazi Üniversitesi Diş Hekimliği Fakültesi Ağız, Diş ve Çene Cerrahisi Ana Bilim Dalı 
antihipoksik, analjezik, hemostatik ve detoks sağlayıcı etkilerdir. ${ }^{1-4}$

Antimikrobiyal etki; Ozon antimikrobiyal etkisini hücre zarında hasar oluşturarak göstermektedir. Hücre zarındaki hidrokarbonların çift bağları ile kimyasal reaksiyona girmekte, ayrıca sekonder oksidan etkiyle hücre içeriğinde modifikasyona sebep olmaktadır. Ozon, antibiyotiğe dirençli türlere oldukça etkilidir. Sıvı ortamda ve asidik $\mathrm{pH}^{\prime}$ da ozonun antimikrobiyal aktivitesi artmaktadır. ${ }^{2}$ Viral enfeksiyonlardaozonun etki mekanizmasının temelinde; enfekte hücrenin peroksit duyarlıı̆ı ve ozonun reverse transkriptaz enziminin aktivitesini değiştirerek viral proteinlerin sentezini engellemesi yatmaktadır. ${ }^{4}$

Immunstimülan etki; Ozon hücresel ve hümoral bağışıklığı etkilemektedir. Bağışıklık sistemi hücrelerinin proliferasyonunu ve immünglobulin sentezini uyarmakta, makrofajların fagositoz için duyarıılığını arttırıken diğer fonksiyonlarını da aktive etmektedir. Bu aktivasyon sonucu sitokin adı verilen özel moleküller üretilir. Bu durum bağışıklık sistemi zayıf veya bağışıklık sisteminde bozukluk olan kişilerde düşük dozlarda ozon uygulamasının yararlı olduğunu göstermektedir. Ozon; interlökinler, lökotrienler ve prostoglandinler gibi biyolojik olarak aktif moleküllerin sentezini de arttırarak inflamasyonun azalmasına ve yara iyileşmesine de yardımcı olmaktadır. ${ }^{2,6}$

Antihipoksik etki; Ozon dokulardaki parsiyel oksijen basıncını ve kandaki oksijen taşınımını arttırarak hücre metabolizmasında değişikliğe neden olmaktadır. Bu değişiklik, oksijenli solunumun ve dolayısıyla enerji kaynaklarının (glikoliz, krebs döngüsü, yağ asitlerinin $\beta$-oksidasyonu) kullanımını arttırmaktadır. Ayrıca eritrositlerin çökmesini önlemekte ve oksijen taşınımı için eritrositlerin temas yüzeyini arttırmaktadır. Dolaşım bozukluğu hastalıklarında, dolaşımı uyarmasında ve organ fonksiyonlarının yeniden canlandırılmasında önemlidir. ${ }^{1,2}$

Analjezik ve detoksifikasyon etkisi: Nitröz oksit (NO) gibi vazodilatörlerin salınımına neden olarak arteriol ve venüllerde dilatasyona sebep olmaktadır. ${ }^{2,3}$

Metabolizma hızı ve biyosentez üzerine etkisi: Mitokondri ve ribozomları uyararak hücre içi protein sentezini arttırmaktadır. Bu değişiklik hücre fonksiyonlarının aktivasyonunu, doku ve organların rejenerasyon potansiyelini açıklamaktadır. ${ }^{2,6}$

\section{Ozon tedavisinin mantıksal temeli}

Ozon tedavisinin neden yapıldığını açıklayan gerekçeler ile uygulanması ve uygulanmaması gereken durumlar bilinmelidir.

\section{- Oksijen/ozon tedavisinin amaclarr: ${ }^{2}$}

1- Patojenlerin yok edilmesi

2- Oksijen metabolizmasının uygun bir şekilde yeniden yapılandırılması

3- Ekolojik çevreye zarar verilmemesi

4- Dolaşımın arttırılması

5- Bağışıklık sisteminin güçlendirilmesi

6- Vücuttaki anti oksidan sistemin uyarılmasıdır.

- Ozon tedavisinin endikasyonları; ${ }^{1-4}$ Ozon tedavisi tıpta çeşitli hastalıkların tedavisinde kullanılmaktadır. Bunlar;

1- Arteriyal dolaşım bozuklukları,

2- Bağışıklık sistemindeki bozulmalar,

- Kanser hastalarında ek tedavi olarak,

- Virüslerin neden olduğu hastalıklarda (ör:HBV),

3- İnflamatuar durumlar,

4- Romatizmal hastalıklar,

5- Deri lezyonları ve eksternal ülserler ile

6- Diş hekimliği uygulamalarıdır.

- Ozon tedavisinin kontrendikasyonları:

1- Hamilelik ,

2- Glukoz-6-fosfatdehidrogenaz enziminin eksikliği ( Favizm ),

3- Kontrol altında olmayan hipertiroidizm, trombositopeni ve ciddi kardio-vasküler durumlar,

4- ACE inhibitörü kullanan hastalar,

5- Ozon alerjisidir.

\section{Uygulama şekilleri: $\mathbf{2 , 4 , 5}^{2}$}

1- Major oto-hemoterapi,

2- Rektal yoldan oksijen/ozon karışımının verilmesi,

3- Minor oto-hemoterapi,

4- Transkutanöz ozon gazı uygulama,

5- Ozonlanmış su ( sprey ya da kompres olarak),

6- Intraartikuler enjeksiyon,

7- İntramuskuler enjeksiyon,

8- Ozonlanmış zeytin yağıdır.

Oral dokularda uygulamaya yönelik ozonlanmış su, ozonlanmış zeytin yağı, oksijen/ozon gaz karışımı olarak 3 temel form kullanılmaktadır: Bu uygulama

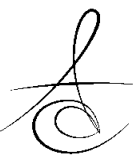


formları tek başlarına veya birlikte dental hastalıkların tedavisinde uygulamaktadır. $^{1}$ Ayrıca yine diş hekimliğinde;

- Çenelerdeki enfekte kemik kavitelerine infüzyon şeklinde,

- Temporpmandibular eklemdeki ağrı ve inflamasyonun tedavisinde infüzyon şeklinde,

- Kök kanal tedavisi yapılırken kanal dezenfeksiyonunu sağlamak amacıyla irrigasyon solüsyonu olarak,

- Ve periodontal hastalıklarda ozonlanmış zeytinyağı ek tedavi olarak kullanılmaktadır. ${ }^{1}$

\section{Ozon gazı üreten sistemler}

1-Corona Discharce Ozon Jeneratörleri:

Corona Discharce yöntemi ile oksijen molekülünün $\left(\mathrm{O}_{2}\right)$ çift bağını elektrik akımı verilmesiyle bozarak diğer serbest kalan oksijen atomu ile birleşmesiyle ozon gazı $\left(\mathrm{O}_{3}\right)$ oluşturulmaktadır. ${ }^{2}$

2-Ultraviole Ozon Jeneratörleri: Ultraviole yöntemi ileoksijen molekülünün 220 nmden daha kısa dalga boyda ışık veren ultraviole ampulünün etrafından geçirilerek parçalanması sağlanmakta ve serbest kalan oksijen atomu diğer oksijen molekülü ile birleşerek ozon gazını oluşturmaktadır. ${ }^{2}$

3- Soğuk Plasma Sistem: Hava ve suyun saflaştırılmasında kullanılmaktadır. ${ }^{2}$

\section{Diş hekimliğinde ozon tedavisi}

Diş hekimliği pratiğinde modern bilim kullanıldıkça diş hekimliği de değiş̧mekte ve gelişmektedir. Ozon tedavisi geleneksel yaklaşımlara alternatif ve/ veya yardımc bir tedavi modeli olarak önümüze gelmektedir. Gelişen teknoloji bizleri daha az invaziv ve daha fazla konservatif çalışmaya yönlendirmektedir. Ozonun diş hekimliğinde kullanılabileceğini akla getiren başlıca özelliği kuvvetli bir antimikrobiyal ajan olmasıdır. Gr $(+,-)$ bakteriler, virüsler ve mantarlara karşı etkinliği kanıtlanmıştır. Diş hekimliğinde protez, endodonti, restoratif diş hekimliği, periodontoloji, oral ve maksillofasiyal cerrahide kullanılmakta olan ozon, geleneksel tedavilere ek olarak çok iyi avantajlar sunmaktadır. $1,2,5$

\section{Kullanım alanları şunlardır: ${ }^{2,7}$}

- Çürük profilaksisi,

- Pit ve fissür, kök veya düz yüzey çürüklerinin remineralizasyonu

- Geleneksel tedaviyle birlikte açılmış kavitelerin restorasyonu,

- Renklenmiş kök kanal tedavili dişlerin ağartılması,

- Endodontik tedavi,

- Kök hassasiyeti olan dişlerin desensitizasyonu,

- Yumuşak doku lezyonlarının tedavisi,

- Enfekte, kötü iyileşen yaraların tedavisidir.

- Cürükten korumada ozon: Ozon güçlü ve güvenilir bir antimikrobiyal ajandır. Çürük yapıcı mikroorganizmalar üzerinde kuvvetli yıkıcı etkilere sahiptir. Yüksek çürük riskli hastaların ozonla tedavisinde çürüğün ilerlemesini anlamlı derecede azalttığı, remiralizasyon sağladığı ve çürüğü durdurduğu görülmüştür. ${ }^{8}$ İlk çalışmalarda kökteki çürük lezyonları klinik olarak ozonla remineralize edilebilmiştir. Ayrıca geleneksel tedaviyle karşılaştırıldığında ozonun non-invaziv olmasının anksiyeteyi de azalttığı klinik deneyimlerde gözlenmiştir. ${ }^{3,7,9}$

- Hipersensitivitede ozon: Gaz halindeki ozon uygulamasının hemen ardından ağrının azaldığı ve hassas dentinde yapılan bu işlemin uzun ömürlü olduğu yapılan çalışmalarla gösterilmiştir. Ozon smear tabakasını yerinden kaldırmakta, dentin tübüllerini açmakta, çaplarını genişletmekte, kalsiyum ve florun kolayca tübüllere girişine yardımcı olmaktadır. Dentin tübülleri böylece etkili ve sıkı bir şekilde tıkanmakta ve böylece tübüldeki SIVı değişimi engellenmektedir. Sonuç olarak ozon kök hassasiyetini etkili ve çabuk bir şekilde üstelik uzun süreli olarak çözmüş olmaktadır. ${ }^{3,7}$

- Endodontide ozon: Ozonun antimikrobiyal etkileri endodontide kullanımını gündeme getirmiştir. Mikroorganizmalar kök kanal tedavisindeki başarısızlık sebeplerinden biridir. Ozon en güçlü antimikrobiyal ajanlardandır ve kök kanal sistemi içindeki mikroorganizma sayısını azaltması önemli bir avantajdır. Çalışmalar ozon gazının ve ozonlanmış suyun veya yağın endodontik amaçla kullanımında etkili olduğunu göstermiştir. ${ }^{10,11}$

Bir başka çalışmada ozonlu $\mathrm{NaClO}$ kullanılmış ve bu solüsyonun $\mathrm{NaClO}^{\prime}$ e göre daha oksidan, antimikrobiyal etkinliğinin daha fazla ve rutin kökkanal tedavisinde daha kısa zamanda sonuç verdiği görülmüştür. ${ }^{12}$

- Restoratif diş hekimliğinde ozon: Ozonun restoratif diş hekimliğinde kulanımı ve dental 
materyaller üzerindeki etkileri çalışmalarla değerlendirilmiş ve sonuç olarak örtücü (sealant) uygulamasında sağlam minenin fiziksel özelliklerini olumsuz etkilememesi için asitlemeden önce uygulanabileceği sonucuna varılmıştır. ${ }^{6}$ Derin kavitelerde uzun süreli ozon gazı uygulaması dentin tübülleri içindeki mikroorganizmalar için bakterisit etki göstererek klinik başarıyı da arttırmaktadır. ${ }^{13}$ Ozon gazı bu etkiyi gösterirken dentin ve mine ile adeziv restorasyon arasında oluşan makaslama kuvveti üzerinde olumsuz bir etki yapmamaktadır. ${ }^{14}$

- Plak biyofilm üzerinde ozonun antibakteriyel etkisi: Çürük ve periodontal hastalıkların birincil sebebi plaktır. Ozonun plak içindeki enfeksiyöz mikroorganizmaların kontrolünde kullanılabileceği gündeme gelmiştir. Ozonun antimikrobiyal özelliği çürük yapıcı bakteri sayısını azaltmada oldukça etkilidir. Ancak ozon plak içerisindeki tüm mikroorganizmaların eliminasyonunu sağlayamamaktadır ${ }^{15,16}$ Ozonlanmış su; periodontal hastalıklara sebep olan $\mathrm{gr}(+,-)$ bakteriler ile Candida albicans'। (C. albicans) da etkili bir şekilde yok edebilmektedir. SIVı formdaki ozon diş hekimliğinde kullanılan diğer antimikrobiyal ajanlara göre daha az sitotoksiktir ve oral uygulamalarda kullanılabilecek biouyumlu bir materyaldir. ${ }^{17,18}$ Bütün bu avantajlar göz önüne alındığında ozonun geleneksel tedaviye ek olarak kullanımı önerilmektedir. ${ }^{3}$

- Oral ve maksillofasiyal cerrahide ozon: Ozonun kemik metabolizması ve kemikteki tamir sürecine pozitif etkisi vardır. ${ }^{19-21}$ Medikal ozon uygulamasıly; kronik mandibular osteomiyeliti olan hastalarda daha hızı iyileşme ve osteomiyelite bağlı komplikasyonlarda azalma olduğu, baş-boyun bölgesinde görülen refraktör osteomiyelitlerin geleneksel tedavilerine ek olarak uygulandığında başarıı sonuçların alındığı, bifosfonat kullanan hastalarda görülen kemik nekroz alanları ve cerrahi olarak sekestrların çıkartılmasından sonra hücre çoğalması ve yumuşak doku iyileşmesinde hızlanma görüldüğü kaydedilmiştir. ${ }^{2}$

Kronik mandibular osteomiyelit hastalarında medikal ozon uygulamasında doğal bağışıklık ve hücresel bağışıklık sistemlerinde hızla normale dönme görülmüştür. Bu da klinik iyileşmenin hızlanmasına ve osteomiyelite bağı komplikasyon gelişiminde azalmaya neden olmuştur. ${ }^{22}$
Ayrıca baş boyun bölgesinde tedaviye yanıt vermeyen osteomiyelitlerde antibiyotik, cerrahi ve hiperbarik oksijen tedavisine ek olarak uygulandığında yararlı olduğu görülmüştür. ${ }^{23}$

Bifosfanat kullanımına bağlı olarak çenelerde gelişen osteonekroz vakalarında ozon kullanımıyla ilgili bir çok çalışma yapılmışıı. Ozonun farklı uygulama yolları ( gaz, ozonlu su veye yağ ) ile yapılan bu klinik çalışmalarda benzer sonuçlar alınmıştır. ${ }^{22,24-27}$

Bifosfanat kullanan multiple myelom hastalarında antibiyotik kullanımına ek olarak, cerrahi işlem ve ozon terapisi birlikte uygulandğında çenelerde osteonekroz insidansı ve lezyonların yayılmasında azalma olduğu, ayrıca bu hastalarda osteonekroza ek olarak görülen ağrı ve halitozis şikayetlerinin de azaldığı görülmüştür. ${ }^{25}$

Ozon terapisi uygulanan avasküler bifosfanat ilişkili osteonekrozu (BRONJ) olan veya pirofosfat analoğu kullanan hastalarda diş çekimlerinin mümkün olabileceğine dair çalışmalar mevcuttur. ${ }^{26}$

Bifosfanat kullanan hastalarda nekroz olan kemiğe yapılacak işlemlerde, ozon terapisinin sahip olduğu hücre proliferasyonunu uyarıc ve yumuşak doku iyileşmesini kolaylaştırıcı etkileri bu tedavinin şekillendirilmesinde göz önünde bulundurulmalıdır. ${ }^{27}$

Bir başka çalışmada ise; BRONJ hastalarının tedavisinde küretajı takiben ozon uygulaması yapılmış, aynı zamanda hastalara $\beta$-laktam antibiyotik, antimikotik, askorbik asit ve $\% 0.02$ ' lik klorheksidin gargara verilmiştir. Hastaların tedavileri sonlandırıldıktan sonra tedavi öncesi ve sonrası ağrı değerlendirmesinde ağrılarının azaldığı, hastalarda semptomların ve lezyonların gerilediği gözlenmiş̧ir. Çalışma sonucunda BRONJ hastalarında önerilen tedavi minimal invaziv cerrahi, antibiyotik ve antimikotik tedaviye ek olarak ozon tedavisidir. ${ }^{28}$

Yeni tedavi protokolü ozon terapisini, BRONJ' da antibiyotik kullanımı ve cerrahi yaklaşımı destekleyici tedavi olarak önermektedir. $24,29,30$

Gömülü 3. Molar dişlerin cerrahisinde ozonun ağrı, şişlik ve trismusa etkilerini inceleyen bir çalışmada sonuç olarak ozon uygulanan grup ve kontrol grubu arasında trismus ve şişlik açısından anlamlı bir fark bulunmazken post-operatif ağrı değerlendirmesinde ozon uygulanan grupta belirgin bir şekilde daha az ağrı olduğu görülmüştür. ${ }^{31}$ 
Temporomandibular eklemin internal düzensizliklerinde ozon uygulamasına bakıldığında; yapılan bir çalışmada ozonun ilaç tedavisiyle birlikte konsevatif bir yaklaşım olabileceği belirtilmiştir. Bilateral olarak internal düzensizliğe sahip redüksiyonlu disk deplasmanına sahip hastalar üzerinde yapılan birçalışmada bir gruba oksijen-ozon gazı karışımı, diğer gruba nonsteroid antienflamatuar ve kas gevşetici uygulanmıştır. Helkimo' nun klinik disfonksiyon indeksine göre yapılan değerlendirmede ozon uygulanan hastaların \% 37' sinde klinik olarak tamamen iyileşme, \% 50' sinde semptomlarda düzelme görülmüş, diğer grubun ise sadece \% 33' ünde klinik gözlemde düzelme olduğu bildirilmiştir. ${ }^{32}$

- Peri-implantitis tedavisinde ozon: Periimplantitisi önlemek için öncelikle plak kontrolü sağlanmalıdır. Ozon; peri-implantitise neden olan mikroorganizmalar için güçlü bir antimikrobiyal ajandır. Ayrıca; ozon doku sirkülasyonunu arttırarak yara iyileşmesine pozitif etki etmektedir. Gaz formdaki veya ozonlanmış su uygulaması ozon uygulanmadan gerçekleşen yara iyileşmesine göre daha iyi ve hızı bir iyileşme sağlamıştır. 3,33

Yapılan bir in-vitro çalışmada Porphyromonas gingivalisîn ( P. Gingivalis ) 144 ppm; 33 mL/s' lik uygulamayla 24 saniyede yüzeyden elimine edildiği, Streptococcus sangiusún P.gingivalis'e göre daha rezistan olduğu görülmüştür. Ozon gazı uygulamasının antimikrobiyal etkisine ek olarak implant yüzey özelliklerini bozmadığı, osteoblastik hücrelerin adezyon ve proliferasyonunu olumsuz etkilemediği görülmüştür. ${ }^{34}$

\section{- Ozonun yara iyileşmesine etkileri; Teorik} olarak yara iyileşmesi 3 aşamada gerçekleşmektedir. 1.aşama inflamasyon basamağıdır. Normalde 2-3 gün sürmektedir. Bu aşamada 80 $\mathrm{mcg} / \mathrm{ml}$ ozon gazı yaranın temizliği için 10-15 dk. uygulanabilmektedir. Travma, diyabet, lokal iskemi, olası antibiyotik direnci sonucunda oluşan bakteriyel enfeksiyon, ozon tedavisi ile müdahale edilmezse kronik hale gelebilmektedir. 2. aşama yaklaşık 2 hafta sürmektedir. Lokal metabolizma ve sitokin üretiminin artışı fibroblast ve keratinosit proliferasyonundaki artışa sebep olmaktadır, bu da hücre dışı matriks sentezini arttırmaktadır. Enfeksiyon geriledikçe ozon konsantrasyonu düşürülmelidir. (2-5 mcg/ml ).Bu aşamalarda gittikçe azaltılan konsantrasyonlarda uygulanan ozon süper enfeksiyonu önlemekle kalmamakta, doku iyileşmesini de hızlandırmaktadır. ${ }^{4}$

Oral kavitede epitel dokunun yara iyileşmesinde ozonun etkisini Filippi isimli bir araştırmacı incelemiştir. Yapılan çalışma sonucunda günlük olarak uygulanan ozonlu suyun yara iyileşmesinin hızında artış sağladığını bulunmuştur. Günlük ozonlu su uygulanan ve uygulanmayan yara bölgeleri karşılaştırıldığında ozonlu suyun fizyolojik iyileşme oranını arttırdığı, ozon tedavisi altındaki hastaların daha hızlı ve sistemik başka bir ilaca intiyaç duymadan kontrol grubuna göre daha hızlı iyileştiği görülmüştür. ${ }^{35}$

Bir başka çalışmada topikal ozonun gingival greftlemedeki yara iyileşmesine etkisi araştırılmıştır. 18 ay takipte kalan hastalarda sitolojik inceleme sonuçları olarak ozon yağı uygulanan grubun kontrol grubuna göre epitel dokularındaki iyileşmenin anlamlı ölçüde daha iyi olduğu görülmüştür. ${ }^{36}$

\section{- Avülse dişin replantasyon öncesinde ozonlu} su ile dekontaminasyonu: Sıvı formdaki ozon oral epitel hücreler, diş etindeki fibroblastlar ve periodontal hücrelerle yüksek oranda biyouyumludur. ${ }^{37,38}$ İzotonik olmayan ozonlu suyla 2 dakikalık irrigasyon ile sadece mekanik temizlik yapılmış olmakla kalmaz, aynı zamanda kök yüzeyinin dekontaminasyonu da sağlanır. Bu uygulamanın kök yüzeyinde kalan periodontal hücrelere herhangi bir olumsuz etki gözlenmemiştir. ${ }^{38}$

- Hareketli protezlerde ozonun antimikrobiyal etkisi: Protezlerde görülen plak birikimi özellikle C. albicans açısından zengindir. Protez stomatitinden korunmak için plak kontrolü önemlidir. Ozonlu su uygulaması protez üzerindeki C.albicans miktarını azaltmak için kullanılabilmektedir. ${ }^{39}$ Ozon kulanımı metisilin dirençli Stafilococcus aureus ( MRSA ) ve virüslerin temizlenmesinde de etkilidir. Parsiyel protezlerin metal iskeletlerinin yüzey temizliğinde de ozon uygulanabilmektedir. ${ }^{40}$ Ozonun direkt gaz halinde uygulanması ozonlu suya göre mikrobisitetkiyi arttırmaktadır. Bu yüzden ozon gazı hareketli protezlerin temizliğinde klinik olarak daha kullanışlı olabilmektedir.

- Dental ünitlerin su sisteminin temizliği: 10 dakikalık ozon uygulaması bakterilerin \%65 ini öldürmekte fakat yüzeyde oluşan istenmeyen biyofilmin hepsini yok edememektedir. ${ }^{41}$ 


\section{Ozonun qüvenilirliği ve toksisitesi}

Ozon uygulamalarının işinin ehli olmayan kişiler tarafından uygulanması ya da yanlış uygulamalar sonucunda felce, bilinç kaybına ve ölümlere neden olduğuna dair yayınlar mevcuttur. Toksisite insidansı oldukça düşüktür. $(\% 0.0007) .{ }^{4}$ Bilinen yan etkiler; gözlerde sulanma, üst solunum yollarında irritasyon, rinit, öksürük, baş ağrısı, nadiren mide bulantısı, kusma, kısa kısa nefes alma, damarlarda şişlik, zayıflayan dolaşım, kalp problemleri ve felçtir. Ozon zehirlenmelerinde hasta supin pozisyonuna getirilmekte, vitamin $\mathrm{E}$ ve $\mathrm{n}$-asetil-sistein ile tedavi edilmektedir. ${ }^{42-45}$

Bilimsel çalışmalar ozonun diş hekimliği pratiğinde gelecek vaat eden bir tedavi ajanı olabileceğini göstermektedir. Ozon; atravmatik uygulanabilmesi, antimikrobiyal etkisi, hastalar tarafından iyi tolere edilebilmesi yanında toksik risk taşıması, yanlış uygulamalarda ölümcül sonuçlar doğurabilmesi ve henüz etki mekanizmasının tam olarak açıklanamaması sebebiyle çoğu araştırmacı ve klinisyen tarafından şüpheyle karşılanmaktadır. Sonuç olarak ozon tedavisi üzerinde daha fazla klinik çalışma yapılarak iyi tanımlanmış parametreler oluşturulmalıdır.

\section{KAYNAKLAR}

1. Saini R. Ozone Therapy in Dentistry: A Strategic Review. Journal of Natural Science, Biology and Medicine. 2011; 2: 151-3

2. Bhateja S. The Miraculous Healing Theraphy; Ozone Theraphy in Dentistry. Indian Journal of Dentistry. 2012; 3: 150-5

3. Das S. Application of Ozone Therapy in Dentistry. Indian Journal of Dental Advancements, 2011; , 3: p:538-42

4. Bocci V.Ozone: A New Medical Drug. 1 ed. Netherlands: 2005. p. 5-234

5. Grootvelt M, Baysan A, Siddiqui N, Sim J, Silwood C. History of Clinical Application of Ozone, Edward Lynch. Ozone: The Revolution in Dentistry. 1 ed London: 2004. p. 23-9

6. Celiberti $P$, Pazera $P$, Lussi $A$. The Impact of Ozone Treatment on Enamel Physical Properties. Am J Dent. 2006; 19: 67-72

7. Abu-Naba'a L, Shorman H, Holmes J, Petersson LG, Tagami J. Evidenced- based Research Into
Ozone Treatment in Dentistry: An Overwiev. Edward Lynch. Ozone: The Revolution in Dentistry, 1 ed, London. 2004: p.73-115

8. Almaz M, Sönmez I. Ozone Therapy in the Management and Prevention of Caries. Journal of the Formosan Medical Association. 2015; 114: 3-11

9. Tahmassebi JF, Chrysafi N, Duggal MS. The Effect of Ozone on Progression or Regression of Artificial Caries-like Enamel Lesions in vitro. Journal of Dentistry. 2014; 42: 167-74

10. Silveira AM, Lopes HP, Siqueira JF Jr, Macedo SB, Consolaro A. Periradicular Repair After Twovisit Endodontic Treatment Using Two Different Intracanal Medications Compared to Single-Visit Endodontic Treatment. Braz Dent J 2007; 18: 299304

11. Kaptan F, Güven EP, Topcuoglu N, Yazici M, Külekçi G. In vitro Assessment of the Recurrent Doses of Topical Gaseous Ozone in the Removal of Enterococcus faecalis Biofilms in Root Canals. Niger J Clin Pract 014;17:573-8

12. Steier L, Steier G. Ozone Application in Root Disinfection. Edward Lynch. Ozone: The Revolution in Dentistry. 1 ed. London. 2004; p. 275-285

13. Polydorou OPK, Hahn P. Antibacterial Affect of an Ozone Device and Its Comparison with Two-Dentin Bonding Systems. Eur J Oral Sci 2006; 114: 349-53

14. Schmidlin PR, Zimmermann J, Bindl A. Effect of Ozone an Enamel and Dentin Bond Strenght. J Adhes Dent. 2005; 7: 29-32

15. Gupta G, Mansi B. Ozone Therapy in Periodontics. J Med Life. 2012: 5: 59-67

16. Srikanth A, Sathish M, Sri Harsha AV. Application of Ozone in the Treatment of Periodontal Disease, J Pharm Bioallied Sci. 2013;5: 89-94.

17. Kshitish D, Laxman VK. The use of Ozonated Water and $0.2 \%$ Chlorhexidine in the Treatment of Periodontitis Patients: A Clinical and Microbiologic Study. Indian J Dent Res. 2010; 21:341-8.

18. Huth KC, Jacob FM, Saugel B, Cappello C, Paschos E, Hollweck R, Hickel R, Brand K. Effect of Ozone on Oral Cells Compared with Established Antimicrobials. Eur J Oral Sci. 2006; 114: 435-40.

19. Frascino AV, Mantesso A, Corrêa L, Deboni MCZ. Aqueous-ozone Irrigation of Bone Monocortical Wounds in Hyperglycemic Rats. Acta Cirúrgica Brasileira. 2013; 28:5: 327-33 
20. Özdemir $H$, Toker $H$, Balcı $H$, Özer $H$. Effect of Ozone Therapy on Autogenous Bone Graft Healing in Calvarial Defects: A Histologic and Histometric Study in Rats. J Periodont Res. 2013; 48: 722-26.

21. Erdemci $F$, Günaydın $Y$, Sencimen $M$, Başsorgun I, Özler $M$, Öter $S$, Gülses A, Günal A, Sezgin $S$, Bayar GR, Doğan N, Gider IK. Histomorphometric Evaluation of the Effect of Systemic and Topical Ozone on Alveolar Bone Healing Following Tooth Extraction in Rats. Int J Oral Maxillofac Surg. 2014; 43: 777-83.

22. Agapov VS, Shulakov VV, Fomchenkov NA. Ozone Therapy of Chonic Mandibular Osteomyelitis. Stomatologia. 2001; 80: 14-7

23. Steinbart $H$, Schulz S,Mutters R. Evaluation of Ozonated Oxygen in an Experimental Animal Model of Osteomyelitis as a Further Treatment Option for Skull-base Osteomyelitis. Eur Arch Otorhinolaryngol 1999; 256: 153-7

24. Agrillo A, Petrucci MT, Tedaldi M, Mustazza MC, Marino SM, Gallucci C, Iannetti G. New Therapeutic Protocol in the Treatment of Avasculer Necrosis of the Jaws. J. Cranifac. Surg. 2006; 17: 1080-3.

25. Petrucci MT, Gallucci C, Agrillo A, Mustazza MC, Foa R. Role of Ozone Therapy in the Treatment of Osteonecrosis of the Jaws in Multiple Myeloma Patients. J of Europen Haematology Assosication. 2007; 92: 1289.

26. Agrillo A, Sassano P, Rinna C, Priore P, Iannetti G. Ozone Therapy in Exrtactive Surgery on Patients Treated With Biphosponates. J. Craniofac. Surg. 2007; 18: 1068-70

27. Vescovi P, Nammour S.Biphosphonate-related Osteonecrosis of Jaw/ BRONJ therapy. A critical Review. Minerva Stomatol 2010;59: 181-203, 20413

28. Agrillo A, Filiaci $F$, Ramieri V, Riccardi E, Quarato D, Rinna C, Gennaro P, Cascino F,Mitro V, Ungari C. Biphosponate-releated Osteonecrosis of the Jaw (BRONJ): 5 year Experience in the Treatment of 131 Cases With Ozone Therapy, Europan Review for Medical and Pharmacological Sciences. 2012; 16:1741-7

29. Brozoski MA, Lemos CA. Da Graça Naclério-Homem M, Deboni MC. Adjuvant Aqueous Ozone in the Treatment of Bisphosphonate Induced Necrosis of the Jaws: Report of Two Cases and Long-term Follow-up. J Minerva Stomatol. 2014;63:35-41

30. Vescovi P, Manfredi M, Merigo E. Adjuvant Treatment Options in the Management of Medication-Related Osteonecrosis of the Jaw, Otto S. Medication-Related Osteonecrosis of the Jaws. 1 ed. Heidelberg. 2015. p. 103-9

31. Kazancıoğlu HO, Kürklü E, Ezirganlı S. Effects of Ozone Therapy on Pain, Swelling, and Trismus Following Third Molar Surgery. International J. Of Oral and Maxillofac. Surg. 2014;43:644-648

32. Daif ET. Role of Intra-articular Ozone Gas Injection in the Management of Internal Derangement of the Tempopmandibular Joint; Oral Surgery Oral Medicine Oral Pathology and Oral Radiology , 2012; 113: 10-4

33. McKenna DF, Farahani AB, Lynch E. The Effect of Subgingival Ozone and/or Hydrogen Peroxide on the Development of Peri-Implant Mucositis. A double Blind Randomizesd Controlled Trial, The International Journal of Oral \& Maxiallofacial Implants. 2013; 28: 1483-9

34. Hauser-Gerspach I, Vadaszan J, Deronjic I, Gass C, Meyer J, Dard M, Waltimo T, Stübinger S, Mauth C. Influence of Gaseos Ozone in Peri-implantitis: Bactericidal Efficacy and Celluler Response. An in vitro Study Using Titanium and Zirconia; Clin. Oral Invest. 2012; 16:1049-59

35. Filippi A. The Influence of Ozonised Water on the Epithelial Wound Healing Process in the Oral Cavity, Deutsche Zahnärztliche Zeitschrift. 1997; 56: $104-8$

36. Patel PV, Kumar S, Vidya GD, Patel A, Holmes JC, Kumar V. Cytological Assessment of Healing Palatal Donor Site Wounds and Grafted Gingival Wounds After Application of Ozonated Oil: An Eighteenmonth Randomized Controlled Clinical Trial. Acta Cytologica. 2012; 56:277-84

37. Huth KC, Jakob FM,Saugel B, Cappello C, Paschos E, Hollweck R, HickelR,Brand K.Effect of Ozone on Oral Cells Compared With Established Antimicrobials. Eur J Oral Sci. 2006; 114: 435-40.

38. EbensbergerU, PohIY, FilippiA. PCNA-Expression of Cementoblasts and Fibroblasts on the Root Surface After Extraoral Rinsing for Decontamination. Dental Traumatology. 2002;18: 262-6.

39. Arita M, Nagayoshi M, Fukuizumi T, Okinaga $T$, Masumi S, Morikawa M,Kakinoki $Y$, Nishihara T. 
Microbicidal Efficacy of Ozonated Water Against Candida albicans Adhering to Acrylic Denture Plates. Oral Microbiology Immunology. 2005; 20: 206-10

40. Suzuki T, Oizumi M, Furuya J , Okamoto Y, Stephen $F$, Rosenstiel SF. Influence of Ozone on Oxidation of Dental Alloys. Int J Prosthodont. 1999; 12: 179-83

41. Walker JT, Bradshaw DJ, Fulford MR, Marsh PD. System Laboratory Model of a Dental Unit Water Mixed-Species Biofilm Contamination in a Disinfectant Products to Control Microbiological Evaluation of a Range ofAppl. Environ. Microbiol. 2003; 69:3327

42. Nogales CG, Ferrari PH, Kantorovich EO, Marques JLL. Ozone Therapy in Medicine and Dentistry. The J Contemporary Dental Practice. 2008; 9: 1-9

43. Bocci V. Is it True that Ozone is Always Toxic? The End of a Dogma, Toxicology and Applied Pharmacology, 2006; 206: 493-504

44. Bocci V, Aldinucci C. Biochemical Modifications Induced in Human Bloodby OxygenationOzonation. J Biochem Molecular Toxicology, 2006; 20: $133-8$

45. Yeğin Z, Tosun G. Diş hekimliğinde Ozon ve Kullanım Alanları, J Dent Fac Atatürk Uni, 2013; 23: $116-22$

\author{
Yazışma Adresi \\ Dt. Hümeyra YAZAR \\ Gazi Üniversitesi Diş Hekimliği Fakültesi \\ Ağız, Diş ve Çene Cerrahisi Anabilim Dalı \\ e-posta: dt.hyazar@gmail.com
}

